FOLIA PRAEHISTORICA POSNANIENSIA T. XXI - 2016

INSTYTUT ARCHEOLOGII, UAM POZNAŃ - ISSN 0239-8524

http://dx.doi.org/10.14746/fpp.2016.21.22

\title{
DAMIAN WASZAK (RED.) CELTICA STUDIA Z DZIEJÓW CELTÓW TOM II, TETRAGON, KALISZ - WARSZAWA 2014
}

W 2013 r. na krajowym rynku wydawniczym zadebiutowała nowa seria, która w zamiarze jej wydawcy miała sprzyjać ,,zapełnieniu luki wśród prac omawiających najdawniejsze dzieje Celtów”. Pierwszy tom istotnie zawierał interesujące teksty, które stanowiły ciekawy przyczynek do polskich studiów nad tą problematyką. Omawiały one sytuację kulturową w ostatniej przystani Celtów, jaką mimo różnych kolei losów pozostała do dziś Irlandia, opisywały pewne epizody tego ludu na obszarze ziem współczesnej Polski i wkraczały $\mathrm{w}$ problematykę celtyckiej wojskowości. Przedstawione w nich drobne prace przyniosły ciekawe ujęcia monograficzne wybranych epizodów z dziejów Celtów. Wolumin ten, zgodnie z planami jego wydawców, dawał dobre podstawy pod zaczątek nowego cyklu wydawniczego, który miałaby stać się forum wymiany myśli między polskimi celtologami. Pojawiało się tylko pytanie, na ile stabilna będzie owa platforma dyskusyjna. Czy dobrze zapowiadająca się seria nie skończy się na jednym sygnalnym tomie. Na całe szczęcie tak się nie stało. Drugi tom Celtici pojawił się bowiem w księgarniach już w kolejnym roku. W zmienionej (zdaniem recenzenta in plus) szacie graficznej twórczo kontynuuje on zamysł przyświecający powstaniu tomu pierwszego. Pojawia się w nim bowiem ponownie interesujący wybór tekstów, poruszających szeroki aspekt problemów dotyczących całej gamy szczegółowych zagadnień z dziejów świata celtyckiego.

Tom II Celtici składa się ze Słowa wstępnego napisanego przez Damiana Waszaka oraz sześciu artykułów zebranych w pięciu częściach tematycznych. Całość zamykają Noty o autorach przedstawiające ich sylwetki badawcze i afiliacje.

Pierwszy blok Irlandia to tekst Michała Norberta Faszcza Raz jeszcze o klientelizmie wschodnich plemion goidelskich, w którym autor kontynuuje rozpoczętą w poprzednim tomie tematykę irlandzką. Prezentuje on koncepcję ciekawą, choć, z uwagi na brak jednoznacznych przekazów źródłowych, trudną do pewnego udowodnienia. Stara się on mianowicie dowieść przez próbę wyjaśnienia zagadnienia zjawiska klienteli społecznej i politycznej u Goidelów, domniemywanego obejmowaniem patronatem niektórych plemion irlandzkich przez celtyckich władców z Brytanii i wiązanego z tym faktem wzrostu atrakcyjności kultury lateńskiej na terenie Irlandii.

Praca Andrzeja Dubickiego Burebista i upadek potęgi celtyckiej nad środkowym Dunajem zamieszczona została w części Celtowie w Europie Środkowo-Wschodniej. Jest to refleksja nad przemianami, jakie zaszły w strefie naddunajskiej w efekcie złamanie potęgi Celtów przez dackiego króla Burebistę. Wydarzenie to, jak wskazuje autor opracowania, zmieniło mapę etniczną tych terenów, co później ułatwiło Germanom opanowanie terytorium 
leżącego na północ od Dunaju. Stało się ono także katalizatorem umożliwiającym czasowe zjednoczenie plemion Daków i Getów, pociągając za sobą jednocześnie - co zostało zauważone w toku wypowiedzi - pewną marginalizację tych ostatnich.

Problematyka kolejnego cyklu dwóch artykułów to Celtowie na ziemiach polskich. W pierwszym z nich Rekonstrukcja staterów kujawskich typu Gąski i Stawęcinek. Mennica celtycka z przełomu er $w$ świetle eksperymentów autorstwa Łukasza Kieferlinga, ukazane zostały najnowsze ustalenia na temat odnalezionych na terenie Kujaw monet celtyckich. Do wniosków autor tekstu doszedł na podstawie analizy technologicznej przeprowadzonej podczas rekonstrukcji stempli na potrzeby miniemisji realizowanej dla Muzeum w Bydgoszczy. W trakcie tych prób na różnych stopach wybito około 30 monet, używając do tego celu zestawu trzech stempli. Efektem tego eksperymentu są prezentowane w recenzowanym opracowaniu argumenty, uzasadniające, że omawiane w nim monety są emisjami lokalnej mennicy, którą autor tekstu lokalizuje na osadzie w Kruszy Zamkowej. Zdaniem Ł. Kieferlinaga wskazywać mogą na to zarówno charakter rysunku, jego ewolucja, jak i stopień zużycia matryc. Te ostatnie, jego zdaniem, opracowane zostały wyłącznie prostym zestawem punc, prawdopodobnie z pominięciem etapu przygotowania matrycy wzorcowej. To także zdaniem autora może przemawiać za lokalną proweniencją omawianej emisji. Próbą dowiedzenia bezpośredniej bytności Celtów na obszarze wschodniej Wielkopolski jest praca Marka Olędzkiego, Leszka Ziąbki i Adam Kędzierskiego Celtowie w międzyrzeczu Prosny $i$ Warty u schyłku epoki La Tene. Dla potwierdzenia zasadności przyjęcia tego typu założenia, autorzy przytaczają odkryte w rzeczonym regionie stanowiska archeologiczne (osady i cmentarzyska) z materiałami kultury lateńskiej. Wskazują oni, że ich zbiór, pochodzący stąd, jest dość pokaźny, a przede wszystkim charakteryzuje się wyraźną spójnością terytorialną (Noricum) i chronologiczną (LT D2).

W dziale Wojskowość zamieszczony został artykuł Damiana Waszaka Bitwa nad rzeka Sabis (57 r. p.n.e.), omawiający epizod kampanii belgijskiej Cezara podczas walki z plemieniem Nerwiów. Opisywane tu zwycięstwo Cezara odniesione w starciu z Nerwiami było niesłychanie ważnym punktem w dziejach wojen toczonych z Galami. Oddało ono w ręce Cezara Belgię, ale jednocześnie pokazało, że Galowie są w stanie zorganizować wspólne i zaplanowane działania militarne. Artykuł streszcza przebieg kampanii, omawia siły zaangażowane w konflikt i ukazuje także jego szerokie tło.

Ostatnia część recenzowanej pracy, Metodologia, przynosi ze sobą szkic Michała Norberta Faszcza Celtologia po Mallorym - nowe perspektywy badawcze. Autor omawia w nim rolę wydanej w 2013 r. książki autorstwa Jamesa P. Mallory’ego The Origins of the Irish, w kontekście jej znaczenia dla współczesnych studiów nad problematyką cywilizacji zachodniogalijskiej, a w szczególności dziejów Irlandii, której mieszkańców Mallory wyłączył z etnosu celtyckiego, podkreślając ich rodziny, goidelski charakter. Sam artykuł jest rozbudowaną i bardzo erudycyjną próbą omówienia najnowszych trendów badawczych nad różnymi aspektami cywilizacji i kultury celtyckiej, widzianymi niewątpliwie przez pryzmat społeczności ,wyspiarskich”. Niemniej wnosi niezwykle ciekawe spostrzeżenia i duży zasób wiedzy źródłowej, przydatnych dla wszystkich zainteresowanych czasami dominanty Celtów w Europie.

Zróżnicowanie problematyki tekstów prezentowanych w poszczególnych częściach recenzowanego manuskryptu daje ciekawe i wieloaspektowe spojrzenie na dzieje świata cel- 
tyckiego. Mimo różnorodności tematycznej, treści zawarte w poszczególnych artykułach składających się na recenzowaną pozycję budują swoją narracją dobrze przemyślaną całość, pozwalającą na wieloaspektowe dostrzeżenie złożoności tej fascynującej cywilizacji europejskiej, jaką tworzyli w czasach swej świetności Celtowie. Śledząc tok zamieszczonych tu tekstów, uzyskujemy szerokie spektrum wypowiedzi opartych na różnych typach dostępnych nam współcześnie źródeł, z których poczesne miejsce uzyskują tu niewątpliwie materiały archeologiczne. Recenzowana praca jest tym samym doskonałą bazą źródłową, możliwą do wykorzystania w trakcie dyskusji toczonych współcześnie nad problematyką fenomenu cywilizacji celtyckiej. Pragnę w tym miejscu wyrazić nadzieję, że omawiany tom nie jest ostatnim i seria ta będzie nadal kontynuowana, a przede wszystkim zasilana przez coraz liczniejszą grupę autorów prezentujących na jej łamach swoje badania nad dziejami Celtów. Jak zaznaczyłem na początku swojej wypowiedzi, tego typu przedsięwzięcie wypełnia bowiem istotną lukę, z jaką mieliśmy dotychczas do czynienia na polskim rynku wydawniczym książki naukowej. Tym samym staje się on potwierdzeniem słuszności wprowadzenia takiego przedsięwzięcia w życie.

Andrzej Michałowski

Instytut Archeologii, Wydział Historyczny Uniwersytet im. Adama Mickiewicza w Poznaniu ul. Umultowska 89D, 61-814 Poznań, Poland misiek@amu.edu.pl 